\title{
Accumulation Trends of Heavy Metals in Cupressus sempervirens and Eucalyptus camaldulensis Trees Grown in Treated Wastewater Irrigated Soil
}

\author{
Abd El-Hamid, E. A. Sherif ${ }^{1}$, Amro, R. Rabie ${ }^{2}$, Ahmed A. Abdelhafez ${ }^{3 *}$
}

\begin{abstract}
This study was performed to investigate the accumulation trends of heavy metals ( $\mathrm{Fe}, \mathrm{Zn}, \mathrm{Mn}, \mathrm{Cu}, \mathrm{Cr}$, $\mathrm{Pb}, \mathrm{Co}$ and $\mathrm{Ni}$ ) in Cupressus Sempervirens and Eucalyptus Camaldulensis trees grown in treated wastewater irrigated soils. To achieve this goal; water, soil and plant samples were collected from a desert forest plantation in Sadat City, Egypt. The obtained results showed that the levels of heavy metals didn't exceed the maximum permissible limits for soil and water. The contents of heavy metals in the organs of trees species grown in treated wastewater irrigated soil were significantly higher than those of the groundwater irrigated one. The highest translocation factor was recorded for root-branches of Cupressus S. irrigated with treated wastewater with average value of 4.6. However, $\mathrm{Pb}$ showed the lowest translocation factor ranging from 0.02 in the leaves-roots of Cupressus $\mathrm{S}$. to 0.8 in the leaves-roots of Eucalyptus C. irrigated with treated wastewater. It can be suggested that the studied tree species can be used for phytoremediation, and also continuous monitoring of heavy metals status in the soil irrigated with treated wastewater is necessary to ensure its safe use.
\end{abstract}

Key Words: Wastewater- Heavy metals- SoilAccumulation- Cupressus S- Eucalyptus C.

\section{INTRODUCTION}

Water is the most important substance for human being and living organisms. Recently, the shortage of natural water resources is of great concern; especially in the Mediterranean countries, with high and increasing needs of water for different applications. Due to the rapid population and industrial growth, there is a need to recycle and use low quality water (drainage and wastewater) for irrigation. The use of wastewater for forest irrigation has proven to be a promising and successful practice for reusing wastewater and timber production (Asano, 1998; Guo, et al., 2002; Angelakis, 2002; Singh and Bhati, 2005 and Sharma and Ashwath, 2006). Wastewater reuse in forest plays an important role for protecting the environment (Stewart and Flinn, 1984), because woody tree species uptake heavy metals into their tissues (Madejo'on, et al., 2006); in addition, it also initiates opportunities for wood biomass production. Wastewaters may contain heavy metals and pathogens (Rattan, et al., 2005 and Toze, 2006). The severity of microbial pathogens is often short-term effect and depending on the type of wastewater and exposure routes for human, animal or environment (Toze, 2006). Unlike organic contaminants and pathogens, heavy metals are considered stable in soil and cannot be degraded by biological or geochemical means (Liu et al., 2012 and Abdelhafez and Li, 2015). Although some of these heavy metals are necessary for plant growth (i.e., $\mathrm{Mn}, \mathrm{Cu}, \mathrm{Ni}, \mathrm{Zn}$, and $\mathrm{Co}$ ), and may correct nutrients deficiency, high concentrations of these metals can adversely affect the physiological performance of growing plants (Feng et al., 2010), and pose potential risks for human and the environment. Therefore, the presence of heavy metals in the agricultural ecosystem is considered a major source of contamination and toxicity in soil (Sharma, et al., 2007) and plant (Gasc'o and Lobo, 2007). Recycled wastewater for agricultural use needs continuous monitoring to ensure its safe use (Emongor and Ramolemana, 2004). In Egypt, there are several forest locations; especially across the Nile delta irrigated with wastewater, i.e., Ismalia, Alexandria, Port Said, Gharbia and Kafr El-Shaikh (SWIM, 2013). The main objective of the current study was to investigate the accumulation trends of heavy metals in soil and trees (Cupressus Sempervirens and Eucalyptus Camaldulensis) irrigated with treated wastewater for successive 17 years.

\section{MATERIALS AND METHODS}

\section{Study location:}

This study was conducted in a desert forest plantation in Sadat City, about $100 \mathrm{~km}$ North West of Cairo Governorate, Minfiya Governorate, Egypt through friendship between China and Egypt in 1998. The studied forest was drip irrigated by mixed treated wastewater (primary treatment) and industrial water effluents. The quantity of irrigation was $1000 \mathrm{~m}^{3} \mathrm{~h}^{-1}$ with duration of irrigation 8 hour day $^{-1}$. In addition, well water was used for irrigation as a control treatment. The study sites were planted with two woody tree species

\footnotetext{
${ }^{1}$ Soils, Water and Environ. Research Institute (SWERI),

Agriculture Research Center (ARC), Giza- Egypt

${ }^{2}$ Forest Department, Horticulture Research Institute,

Agriculture Research Center (ARC), Giza- Egypt

${ }^{3}$ Department of Soils and Water, Faculty of Agriculture,

Assiut University (the New Valley Branch), New Valley- Egypt

E-mail addresses correspondence: ahmed.aziz@aun.edu.eg

Received May 1, 2017, Accepted May 31, 2017
} 
namely, Cupressus Sempervirens, which belongs to Cupressaceae family, and Eucalyptus Camaldulensis of Myrtaceae family. These trees have been suggested for their potential for phytoremediation of heavy metals because they have provides several attributes, i.e., high biomass, genetic variability and have a good seeing.

\section{Water sampling:}

Water samples (groundwater and treated wastewater) were collected from the studied sites in $500 \mathrm{~mL}$ polypropylene vials. Water samples were allowed to pass through a $0.45 \mu \mathrm{m}$ filter in order to remove any suspended materials, and then $\mathrm{pH}$ and $\mathrm{EC}$ were measured in situ. To avoid the precipitation of metal ions, drops of $1 \mathrm{M} \mathrm{HCl}$ were added to water samples (Abdelhafez and Li, 2014). The collected water samples were analyzed within 24 hours of sampling time.

\section{Soil sampling and preparation:}

Surface soil samples $(0-30 \mathrm{~cm})$ were collected from the groundwater and treated wastewater irrigated soils. The samples were air dried, grinded, sieved to pass through a $2 \mathrm{~mm}$ sieve and analyzed for the main physicochemical parameters as follows: Particle size distribution was carried out according to the International Pipette Method (Piper, 1950). Available forms of elements were extracted by AB-DTPA according to Soltanpour and Schwab (1991). Total elements contents were determined according to Cottenie et al. (1982). Soil $\mathrm{pH}$ and EC were measured in 1:1 soil to water suspension and supernatant, respectively (Jones, 2001). Soil organic matter content was determined by the back titration method (WalkleyBlack procedure) (Nelson and Sommers, 1996). The physical and chemical characteristics of studied soils are shown in Table (1).

\section{Plant sampling and preparation:}

At the end of the each season (spring, summer, autumn, and winter seasons) of 2015/2016, plant samples of Cupressus Smepervirens and Eucalyptus Camaldulensis were taken from three parts (leaves, branches and roots) from the same soil sampling locations. Plant samples were washed with tap water several times then deionized water, and the plant materials were oven-dried at $70^{\circ} \mathrm{C}$ for $48 \mathrm{~h}$. A $0.2 \mathrm{~g}$ of oven dried plants was wet-digested by adding $10 \mathrm{~mL}$ nitric acid $(60 \%)$ and $2 \mathrm{~mL}$ hydrogen peroxide (30\%) (Chapman and Pratt, 1961).

\section{Accumulation and translocation of heavy metals in the growing trees:}

It is well known that bioaccumulation factor (BAF) and translocation factor (TF) have been widely used for this purpose by measuring the transformation of heavy metals from soil to plant roots or branches. However, in this study we aimed to measure the bioaccumulation factor form soil to plant roots, branches and leaves, and translocation factor from roots to branches and from roots to leaves to determine the accumulation trends of heavy metals in the growing trees species. Accumulation and translocation of the studied heavy metals were calculated as follows:

Bioaccumulation factor (BAF): It is defined as the ratio between total heavy metal concentrations in tree tissues and total heavy metals contents.

$\mathrm{BAF}=$ Element concentration in tree tissues, $\mathrm{mg} \mathrm{kg}^{-}$ 1/ Element concentration in soil solution, $\mathrm{mg} \mathrm{kg}^{-1}$.

Translocation factor (TF): It is defined as the total element concentration in branches ( $\mathrm{TF}$ branches/root) and leaf ( $\mathrm{TF}$ leaves/root) with respect to total element concentration in roots (Fitz and Wenzel, 2002).

$\mathrm{TF}=$ Element concentration in tree tissues, $\mathrm{mg} \mathrm{kg}^{-1} /$ Element concentration in root, $\mathrm{mg} \mathrm{kg}^{-1}$

\section{Metal analysis:}

The concentrations of $\mathrm{Fe}, \mathrm{Zn} . \mathrm{Mn}, \mathrm{Cu}, \mathrm{Cr}, \mathrm{Pb}, \mathrm{Ni}$ and $\mathrm{Co}$ were measured in water, soil and plant samples and digest extracts by using ICP-instrument (ICP-JY Ultima) according to the procedure of Environmental Protection Agency (EPA, 1991).

\section{Statistical Analysis:}

The obtained results were statistically analyzed using the SAS package (ver. 9.1). One way ANOVA test was performed and Tukey's honestly significant difference (HSD) studentized range test was applied to attain the significant differences between means $(P<0.05)$.

Table 1. The main physicochemical characteristics of the studied soil

\begin{tabular}{llllllll}
\hline \multicolumn{2}{l}{ Particle size distribution, \% } & \multicolumn{3}{c}{ pH } & EC, $\mathbf{d S ~ m}^{-\mathbf{1}}$ & OM, \% & Textural class \\
$\begin{array}{l}\text { Coarse } \\
\text { sand }\end{array}$ & $\begin{array}{l}\text { Fine } \\
\text { sand }\end{array}$ & Silt & Clay & & & & \\
\hline 80.55 & 14.35 & 2.4 & 2.7 & $8.0 \pm 0.2$ & $2.15 \pm 0.05$ & $0.77 \pm 0.02$ & Sand \\
\hline
\end{tabular}




\section{RERSULTS AND DISCUSSION}

\section{Water analysis:}

Table (2) shows the chemical analysis of the ground water and treated wastewater, used for irrigation. The results showed that the $\mathrm{pH}$ of treated wastewater was slightly higher than the water-quality guidelines for irrigation of FAO (1985). In addition, the EC value of treated wastewater characterized as slightly salt according to FAO guidelines (1985. The EC value of the treated wastewater was higher than $1 \mathrm{dS} \mathrm{m}^{-1}$, indicating the nature salinity of sewage (Rattan et al., 2005). Generally, the concentrations of all studied heavy metals didn't exceed the maximum permissible limits for irrigation according to FAO regulations (Ayers and Westcott, 1985). However, Cu showed a different trend, its concentration was 1.6 times the FAO standard. Furthermore, the concentrations of the studied heavy metals in the treated wastewater were much higher than those of groundwater. The concentrations of $\mathrm{Fe}, \mathrm{Zn}, \mathrm{Mn}$ and $\mathrm{Pb}$ in the treated wastewater were 9.5, 15.0, 9.8 and 6.9 times their concentrations in the groundwater. In spite of the levels of heavy metals in the treated wastewater were not much high; however, their concentrations pose a potential threat for soil under long term of irrigation. This was a remarkable evident for the potential accumulation of these heavy metals in the soil.

\section{Soil analysis:}

The concentrations of studied heavy metals (total and available contents) are presented in Table (3). There are significant elevations of heavy metals in the soils irrigated with treated wastewater compared to the soil irrigated with groundwater. Generally, the total contents of the studied heavy metals didn't exceed the maximum allowable limits in soil (Ewers, 1991 and Pendias and Pendias 1992). The concentrations of $\mathrm{Zn}, \mathrm{Mn}, \mathrm{Cu}, \mathrm{Cr}$ and $\mathrm{Pb}$ were significantly high in the soil irrigated with the treated wastewater; especially the soil planted with Eucalyptus C. trees. There were no significant different Table 2. Chemical characteristics of the studied waters

\begin{tabular}{lcccccccc}
\hline Parameter & \multirow{2}{*}{ Unit } & \multicolumn{3}{c}{ Ground water } & \multicolumn{3}{c}{ Treated wastewater } & FAO Standard \\
\cline { 3 - 7 } & & min. & max. & average & min. & max. & average & $(\mathbf{1 9 8 5})$ \\
\hline $\mathrm{pH}$ & & 6.6 & 8.04 & 7.53 & 8.01 & 8.06 & 8.03 & $6.5-8$ \\
$\mathrm{EC}$ & $\mathrm{dS} \mathrm{m}^{-1}$ & 0.6 & 1.55 & 0.93 & 1.61 & 1.80 & 1.72 & $0.7-3.0$ \\
$\mathrm{Fe}$ & 7.0 & 16.0 & 12.3 & 64.0 & 216.0 & 117.3 & 500.0 \\
$\mathrm{Zn}$ & & 1.0 & 9.0 & 3.5 & 22.0 & 96.0 & 53.0 & 200.0 \\
$\mathrm{Mn}$ & 1.0 & 28.0 & 10.3 & 5.0 & 180.0 & 101.0 & 200.0 \\
$\mathrm{Cu}$ & & 5.0 & 8.0 & 6.8 & 18.0 & 38.0 & 28.0 & 17.0 \\
$\mathrm{Cr}$ & \multirow{2}{*}{$\mathrm{g} \mathrm{L} \mathrm{L}^{-1}$} & n.d. & 6.0 & 2.3 & 1.0 & 13.0 & 6.0 & 550 \\
$\mathrm{~Pb}$ & & 0.5 & 1.0 & 0.8 & 2.0 & 11.0 & 5.5 & 65.0 \\
$\mathrm{Co}$ & & n.d & 1.0 & 0.8 & 2.0 & 6.0 & 3.8 & 50.0 \\
$\mathrm{Ni}$ & & 0.5 & 2.0 & 1.1 & 0.5 & 6.0 & 2.4 & 1400.0 \\
\hline
\end{tabular}

between the total concentrations of $\mathrm{Fe}, \mathrm{Ni}$ and $\mathrm{Co}$ in the studied soils (Table 3). However, the available amounts of $\mathrm{Fe}$ and $\mathrm{Ni}$ were much higher in the soils irrigated with treated wastewater in comparison with those irrigated with ground water. The available forms of Fe in the soils irrigated with treated waste water were almost 2.5 times the soil irrigated with ground water. As mentioned above, the continuous load of these heavy metals into soil through irrigation with wastewater might pose a potential threat to raise the levels of heavy metals in the irrigated soil. As indicated in Table (2) heavy metals concentrations of wastewater were higher than those of groundwater. Therefore, the excessive and continuous irrigation with treated wastewater were believed to be a major factor responsible for soil enrichment with heavy metals. The available amounts of the studied heavy metals were low compared to their total contents, and this could be attributed to high soil $\mathrm{pH}$, that may led to increase the precipitation reaction of these metal ions (Lee and Saunders, 2003); in addition to the differences in the chemical manner of the investigated metal ions (Abdelhafez et al., 2012). Abdelhafez and Li (2015) showed that the use of Jinxi river water contaminated with heavy metals led to accumulate heavy metals in the soil and the growing plants. Furthermore, Tabari and Salehi, (2009) showed that the concentrations of some heavy metals in some water and soil irrigated with treated wastewater exceeded the toxicity limit that may pose potential environmental and health risks in the long-term.

\section{Heavy metals contents in plants:}

Table (4) shows the contents of $\mathrm{Fe}, \mathrm{Zn}, \mathrm{Mn}, \mathrm{Cu}, \mathrm{Cr}$, $\mathrm{Pb}, \mathrm{Ni}$ and $\mathrm{Co}$ in roots, branches and leaves collected from Cupressus Sempervirens and Eucalyptus Camaldulensis trees. The concentrations of $\mathrm{Fe}, \mathrm{Cu}, \mathrm{Cr}$, $\mathrm{Pb}, \mathrm{Ni}$ and $\mathrm{Co}$ tended to accumulate in roots and branches tissues. While the concentrations of $\mathrm{Zn}$ and $\mathrm{Mn}$ tended to accumulate in leaves.

\footnotetext{
"not detected
} 


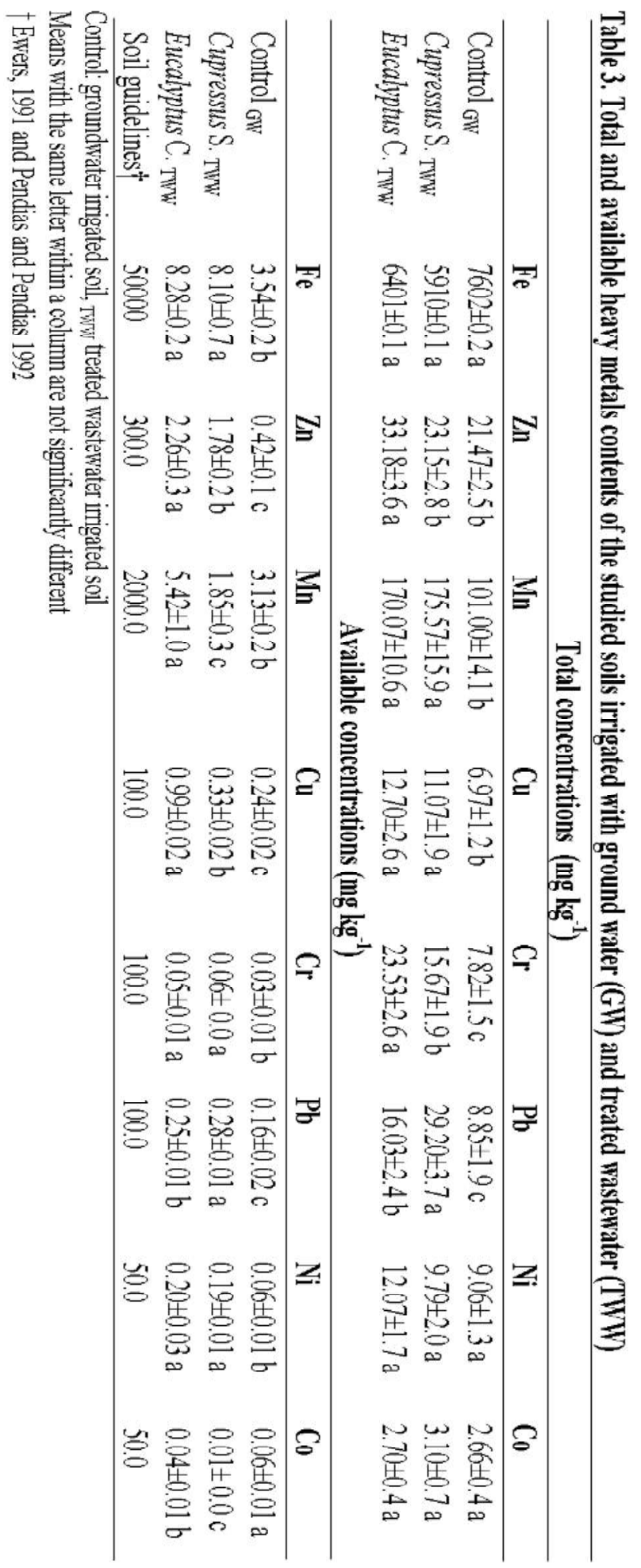




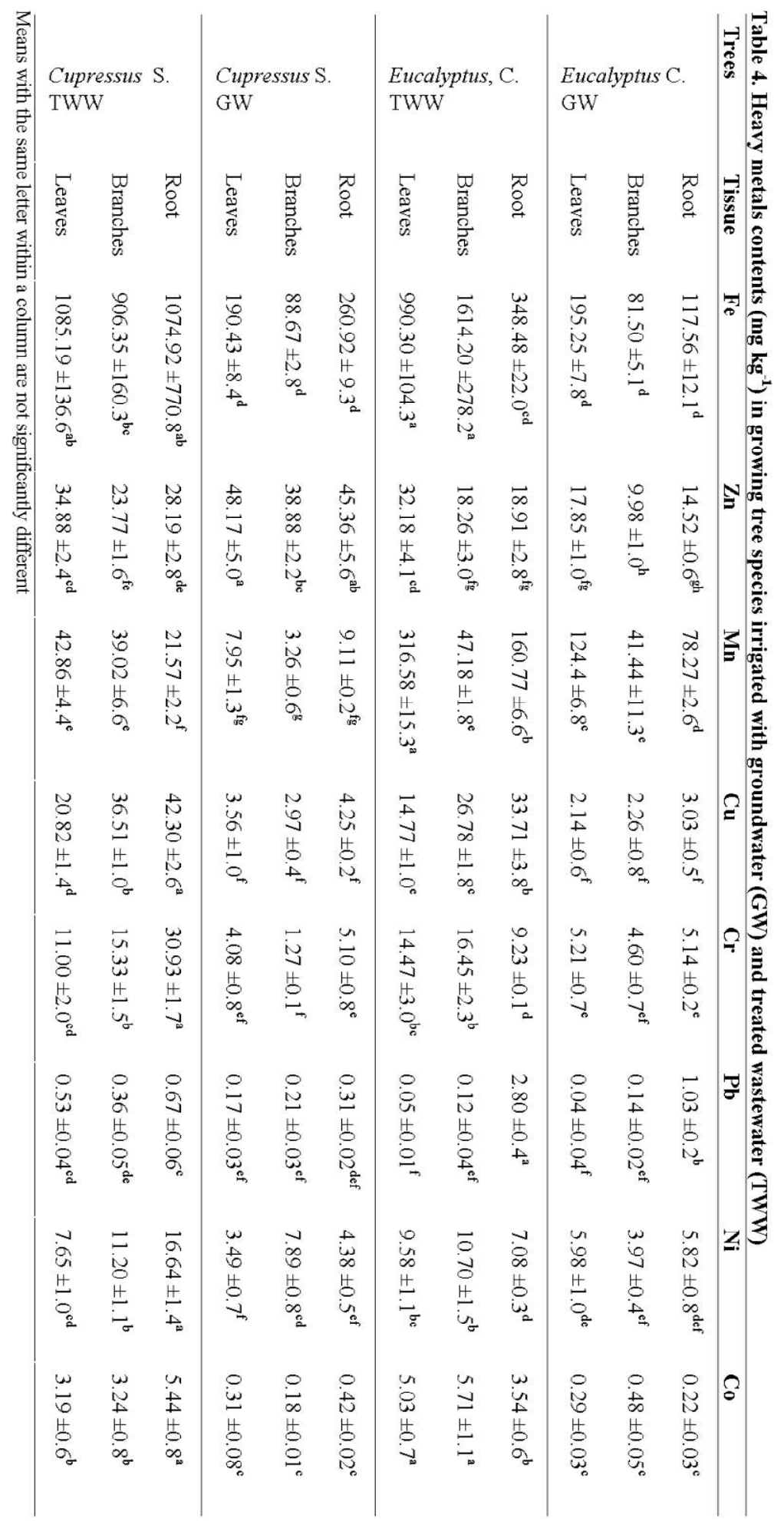


The results also showed that contents of heavy metals in trees species grown on soil irrigated by treated wastewater were significantly higher than those irrigated by groundwater. Although, some of these heavy metals are necessary or favorable for plant growth (i.e., Mn, $\mathrm{Cu}, \mathrm{Ni}, \mathrm{Zn}$, and $\mathrm{Co}$ ), high concentrations of these metals can adversely affect the physiological processes for growing plants (Feng et al., 2010). Abdelhafez and Li (2015) mentioned that heavy metals uptake by the growing plants is a function of soil $\mathrm{pH}$, metal concentrations in soils, organic matter content, cation exchange capacity, types and varieties of plants and plant age. Furthermore, they have declared that many plant species have a native ability to metabolize a variety of heavy metals based on their physiological performance. Whereby, plants varied in their ability to uptake and accumulate heavy metals. Therefore, plant type is a prominent and effective factor for heavy metals uptake. The highest concentration of $\mathrm{Fe}$ was recorded in the branches of Eucalyptus C. irrigated with treated wastewater, which was 1.8 times the concentration of Fe in the branches of Cupressus S. grown at the same location. Generally, the concentrations of $\mathrm{Zn}$ in trees organs can be arranged in the following descending order, leaves $>$ root $>$ branches for Eucalyptus C. and Cupressus S. The highest concentration of $\mathrm{Ni}$ was recorded in the roots of Eucalyptus C. tree grown on treated wastewater irrigated soils $\left(16.6 \mathrm{mg} \mathrm{kg}^{-1}\right)$, which was higher 4 times the Eucalyptus C. roots grown on ground water irrigated soils. In addition, the levels of Co in Cupressus S. and Eucalyptus C. trees grown on treated wastewater irrigated soils were higher 12 to 18 and 10 to 18 times compared to those grown on groundwater irrigated one, respectively. It has been reported that, the contents of heavy metals were primarily dependent on the levels of their contents in soil and secondary on the type of tree species (Abdelhafez and Li, 2015). The branches and leaves of the cultivated trees can be used in several applications, i.e., animal bedding, biomass for burning, chipboard and compost manufacturing (MESA, 2009 and British Standard Institution 2012). Therefore, in this study we have compared the concentrations of the studied heavy metals with the maximum allowable concentrations of heavy metals in woods for different applications according to the British Standard Institution (2012). The obtained results showed that the cultivated trees can be used safely for the above mentioned applications as their contents of heavy metals didn't exceed the upper limits of 200, 100, 200 and $50 \mathrm{mg} \mathrm{kg}^{-1}$ for $\mathrm{Cu}, \mathrm{Cr}, \mathrm{Pb}$ and $\mathrm{Ni}$, respectively. However, attention should be paid regarding the buildup of heavy metals levels in the soils; consequently, their levels in the growing trees.
Therefore, continuous monitoring is essential to ensure their safe use.

\section{Accumulation and translocation of heavy metals in the growing trees:}

The obtained results showed that Cupressus S. accumulates much amount of $\mathrm{Zn}$ compared to Eucalyptus C. However, Eucalyptus C. showed higher accumulation trend for Mn compared to Cupressus $\mathrm{S}$ (Figure 1). The transfer of heavy metals into plant tissues led to values of BAF $>1$ for all heavy metals, except $\mathrm{Fe}$ and $\mathrm{Pb}$. A BAf $>1$ indicates the potential ability of the growing plants for metal accumulation $(\mathrm{Zu}$ et al., 2005). Therefore, the obtained results showed that both trees can accumulates much amounts of heavy metals in their tissues. For this concern, the studied trees species can be used for the remediation of heavy metals contaminated soils. Abbas and Abdelhafez (2013) showed that the available amounts of As (AB-DTPA extractable As) was more suitable to calculate the bioaccumulation factors of maize root $\left(\mathrm{BAF}_{\text {root }}\right)$ and shoot $\left(\mathrm{BAF}_{\text {shoot }}\right)$. Therefore, additional studies are needed to investigate the differences between heavy metals forms and metal ions uptake. For the translocation factors (TFs), the obtained results showed that root-branches and root-leaves translocation factors (TFs) increased with the increase of heavy metals contents in the studied soils (Figure 2). The translocation of $\mathrm{Fe}, \mathrm{Zn}$ and $\mathrm{Mn}$ from roots was more favorable to leaves. While, other studied heavy metals showed a high translocation factor from roots to branches. The highest translocation factor was recorded for root-branches of Cupressus S. irrigated with treated wastewater with an average value of 4.6. However, $\mathrm{Pb}$ showed the lowest translocation factor ranging from 0.02 in the leaves-roots of Cupressus S. to 0.8 in the leaves-roots of Eucalyptus $\mathrm{C}$. both irrigated with treated wastewater.

\section{CONCLUSIONS}

The obtained results showed that the primary treated wastewater couldn't achieve a complete removal of heavy metals. High concentrations of heavy metals were recorded in the treated wastewater compared to the groundwater. The treated wastewater has been intensively used for irrigation for long time ( $>17$ years); consequently, the levels of $\mathrm{Fe}, \mathrm{Zn}, \mathrm{Mn}, \mathrm{Cu}, \mathrm{Cr}, \mathrm{Pb}, \mathrm{Ni}$ and $\mathrm{Co}$ in the irrigated soils were high compared to the ground water irrigated soil. In spite of the levels of heavy metals in the irrigated soils didn't exceed the maximum permissible limits; the continuous application of the treated wastewater may pose a potential threat to increase the levels of heavy metals to reach the maximum allowable concentrations. 

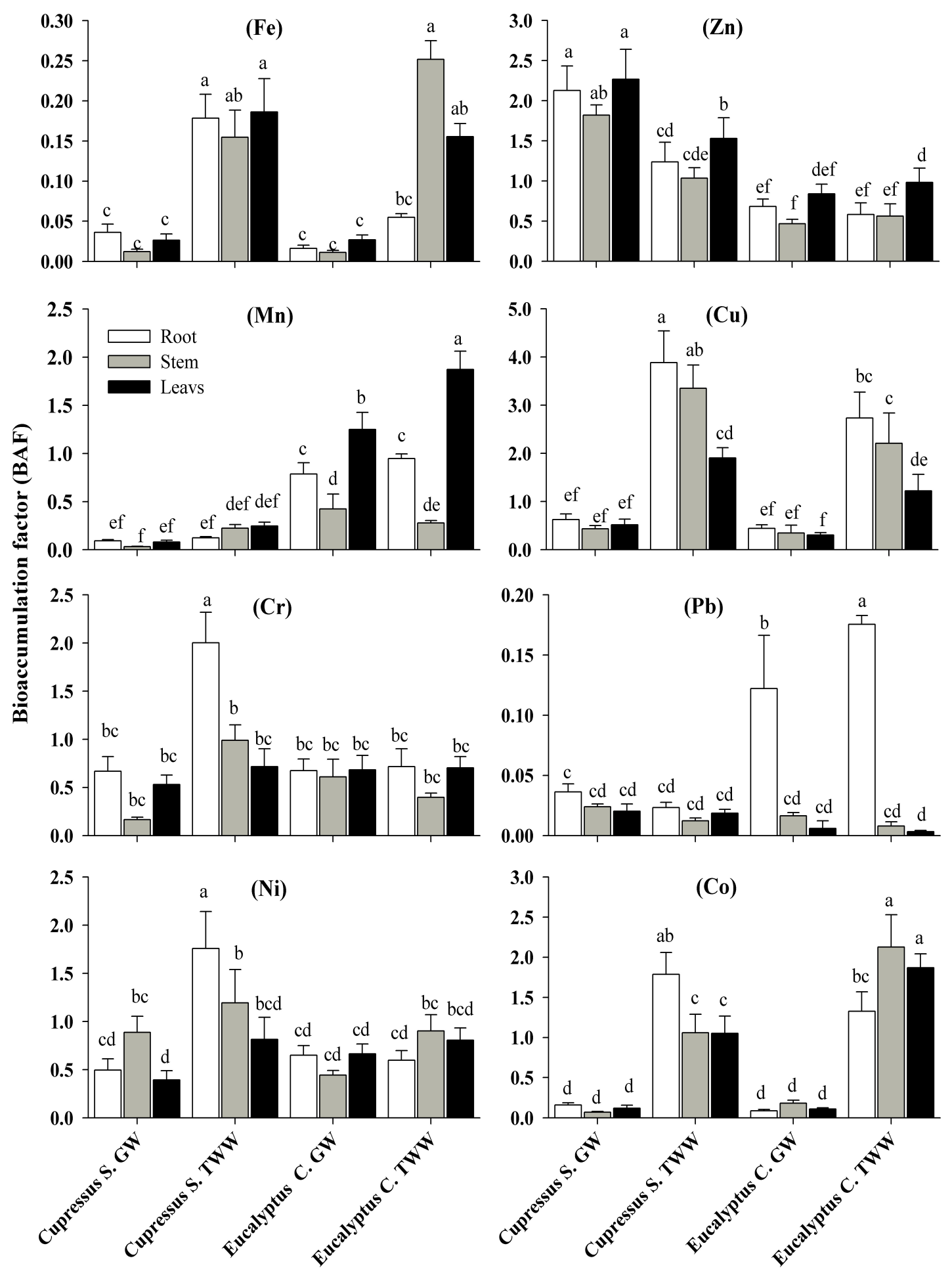

Figure 1. Bioaccumulation factors of the growing tree species irrigated with ground water (GW) and treated wastewater (TWW). Columns with the same letter are not significantly different 

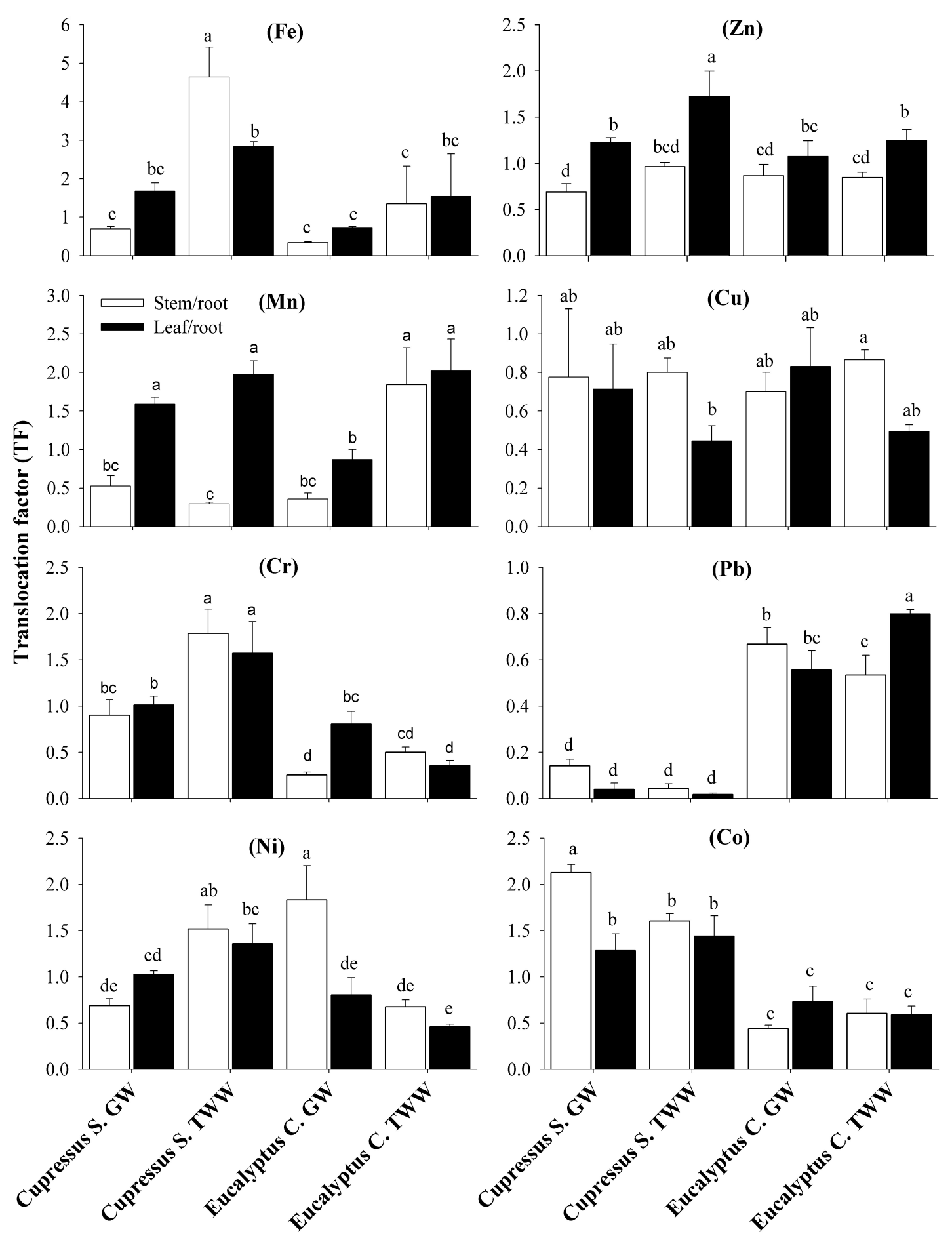

Figure 2. Translocation factors of the growing tree species irrigated with ground water (G.W.) and treated wastewater (TWW). Columns with the same letter are not significantly different 
The results showed the ability of Cupressus S. and Eucalyptus C. trees to accumulate heavy metals in their tissues. However, the levels of heavy metals didn't exceed the maximum permissible limits; therefore, the trees can be used safely for different applications, i.e., composting and wood manufacturing. In addition, they can be used for the phytoremediation of heavy metals contaminated soils. The role of metal ions availability was visible for metal ions contents and translocation. We concluded that, continuous monitoring of heavy metals levels in the treated wastewater irrigated soils is necessary to ensure the safe use of soil. Furthermore, we recommend adding sorbent material during the primary treatment of wastewater to achieve complete removal of toxic heavy metals and increasing the area of woody trees species in the Egyptian forestry. In addition, future studies are needed to investigate the role heavy metals fractions in soil for metal ions uptake and translocation.

\section{REFERENCES}

Abbas M. H. H. and A. A. Abdelhafez. 2013. Role of EDTA in arsenic mobilization and its uptake by maize grown on an As-polluted soil. Chemosphere 90: 588-594.

Abdelhafez A. A. and J. Li. 201 \&. Geochemical and statistical evaluation of heavy metal status in the region around Jinxi River, China. Soil Sediment Contam 23:850-868.

Abdelhafez A. A. and J. Li. 2015. Environmental Monitoring of Heavy Metal Status and Human Health Risk Assessment in the Agricultural Soils of the Jinxi River Area, China. Hum Ecol Risk Assess 21(4): 952-971.

Abdelhafez, A. A., H. H. Abbas, R. S. Abd-El-Aa, N. F. Kandil, J. Li and W. Mahmoud. 2012. Environmental and health impacts of successive mineral fertilization in Egypt. Clean 40: 356-363.

Angelakis, A. N. 2002. Wastewater reclamation and reuse practices in Mediterranean region. WHO regional Office for Europe, EURO Project Office, MAP, Athens, Greece, 2002; pp. vi, 78.

Asano, T. 1998. Wastewater reclamation and reuse. Water Quality Management Library Vol. 10. Technomic Publishing Inc., Lancaster, Pennsylvania, USA.

Ayers, R. S. and D. W. Westcott. 1985. Water quality for agriculture. FAO Irrigation and Drainage Paper 29, Rome.

British Standard Institution. BSI. 2012. Specification for the requirements and test methods for processing waste wood (PAS 111:2012). Publicly Available Specification. London. $\quad$ http://www.woodrecyclers.org/wpcontent/uploads/2015/04/PAS111.pdf

Chapman, H. D. and P. F. Pratt. 1961. Methods of Analysis for Soil, Plants and Waters, University of California, Berkeley.
Cottenie, A., M. Verloo, L. Kiekens, G. Velgh and R. Camerlynch. 1982. Chemical analysis of plants and soils, Lab, Anal Agrochem. State Univ. Ghent Belgium, 63.

Emongor, V. E. and G. M. Ramolemana. 2004. Treated waste water effluent (water) potential to be used for horticultural production in Botswana. Phys Chem Earth 29: 11011108.

Ewers, U. 1991. Standards, guidelines and legislative regulations concerning metals and their compounds. In: Merian E, ed. Metals and Their Compounds in the Environment: Occurrence, Analysis and Biological Relevance. Weinheim: VCH, pp: 458-468.

Environmental Protection Agency (EPA). 1991. Methods for the determination of metals in environmental samples. Office of Research and Development. Washington DC 20460.

Feng, J., Q. Shi, X. Wang, M. Wei, F. Yang and H. Xu. 2010. Silicon supplementation ameliorated the inhibition of photosynthesis and nitrate metabolism by cadmium (Cd) toxicity in Cucumis sativus L. Sci Hortic 123: 521-30.

Fitz, W. J. and W. W. Wenzel. 2002. Arsenic transformations in the soil-rhizosphereplant system: fundamentals and potential application to phytoremediation. J Biotechnol 99: 259-278.

Gasc'o, G. and M. C. Lobo. 2007. Composition of Spanish waste water sludge and effects on treated soil and olive trees. Waste Manag 27(11): 1494-1500.

Guo, L. B., R. E. H. Sims and D. J. Horne. 2002. Biomass production and nutrient cycling in Eucalyptus short rotation energy forests in New Zealand. I: biomass and nutrient accumulation. Bioresour Technol 85: 273-283.

Jones, J. B. 2001. Laboratory Guide for Conducting Soils Tests and Plant Analysis. CRC Press, Boca Raton, FL, USA.

Lee, M. K. and J. A. Saunders. 2003. Effects of pH on metals precipitation and sorption: Field bioremediation and geochemical modeling approaches, Vadose Zone J 2: 177185.

Liu, J., J. Wang, J. Qi, X. Li, Y. Chen, C. Wang and Y. Wu. 2012. Heavy metal contamination in arable soils and vegetables around a sulfuric acid factory, China. Clean 40:766-72

Madej'on, P., T. Mara ñ'on and J. M. Murillo, 2006. Biomonitoring of trace elements in the leaves and fruits of wild olive and holm oak trees. Sci Total Environ 355: 187-203.

MESA, 2009. Ministry of State for Environmental Affairs. http://www.eeaa.gov.eg/English/main/about.asp (Accessed June 2016).

Nelson, D. W. and L. E. Sommers. 1996. Total carbon, organic carbon, and organic matter, in: Page, AL (Eds), Methods of Soil Analysis Part 3, 2nd edit, pp 961-1010. American Society of Agronomy, Madison, WI, USA. 
Pendias, A. K. and H. Pendias. 1992. Elements of Group VIII. In: Trace Elements in Soils and Plants. Boca Raton: CRC Press, pp: 271-276.

Piper, C. S. 1950. Soil and Plant Analysis. Inter. Science Publishers Inc., New York.

Rattan, R. K., S. P. Datta, P. K. Chhonkar, K. Suribabu and A. K. Singh. 2005. Long-term impact of irrigation with waste water effluents on heavy metal content in soils, crops and groundwater - A case study. Agric Ecosyst Environ 109: 310-322.

Sharma, A. and N. Ashwath . 2006. Land disposal of municipal effluents: Importance of choosing agroforestry systems. Desalination 187: 361-374.

Sharma, R. K., M. Agrawal and F. Marshall. 2007. Heavy metal contamination of soil and vegetables in suburban areas of Varanasi, India. Ecotoxicol Environ Saf 66: 258266.

Singh, G. and M. Bhati. 2005. Growth of Dalbergia sissoo in desert regions of western India using municipal effluent and the subsequent changes in soil and plant chemistry. Bioresour Technol 96: 1019-1028.

Soltanpour, P. N. and A. P. Schwab. 1991. Determination of nutrient availability element toxicity by AB-DTPA. Soil Test and ICPS Adv. Soil Sci 16: 165- 190.
Stewart, H. T. L. and D. W. Flinn. 1984. Establishment and early growth of trees irrigated with wastewater at four sites in Victoria, Australia. For Ecol Manage 8: 243-256.

Sustainable Water Integrated Management (SWIM) - Support Mechanism. 2013. Documentation of best practices in increased efficiency in wastewater reuse in selected Mediterranean countries -Egypt, Israel, Jordan \& Morocco.

Tabari, M. and A. Salehi. 2009. Long-term impact of municipal sewage irrigation on treated soil and black locust trees in a semi-arid suburban area of Iran. J Environ Sci 21: 1438-1445

Toze, S. 2006. Reuse of effluent water-benefits and risks. Agric Water Manage 80: 147-159.

Uchida, S., K. Tagami and I. Hirai. 2007. Soil-to-plant transfer factors of stable elements and naturally occurring radionuclides: (2) rice collected in Japan. J Nucl Sci Technol 44: 779-790.

Zu, Y. Q., Y. Li, J. J. Chen, H. Y. Chen, L. Qin and C. Schvartz. 2005. Hyperaccumulation of $\mathrm{Pb}, \mathrm{Zn}$ and $\mathrm{Cd}$ in herbaceous plants grown on lead-zinc mining area in Yunnan. China. Environ Int 31: 755-762. 


\section{الملخص العربي \\ اتجاه تراكم العناصر الثقيلة في أثنجار السرو والكافور البلاى النامية في الأرض المروية بمياه الصرف المعالجة}

عبد الحميد الغضبان عبد الطيف شريف، عمرو رافت ربيع، أحمد عزيز الدين أبوبكر عبد الحافظ

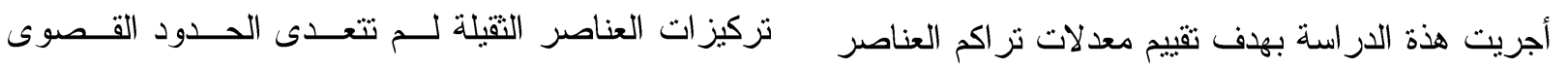

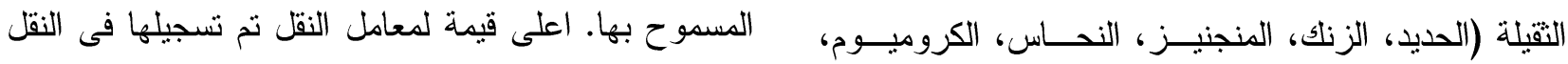

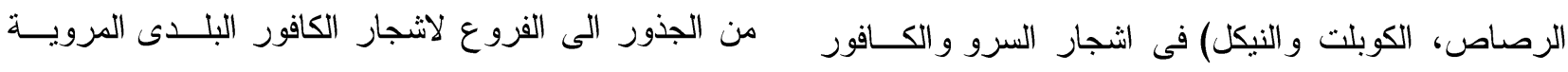

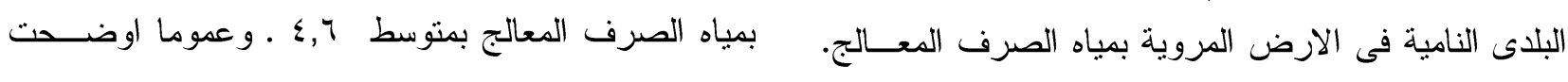

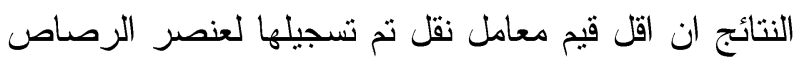

وتز اوحت القيم من r +, • فى النقل من الجذور للاوراق فى ولتحقيق ذلك، نم تجميع عينات من المياه و التزبة و النباتات اشجار الكافور البلدى الى ^, • نقل من الجذور الى الاوراق

من منطقة الزر اعات الخشبية في مدينة السادات بمحافظـــة فى اشجار السرو وكلاهما تم رية بمياه الصرف المعــالج. ونستخلص من الدراسة ان اثجار النباتات موضع الدراسة

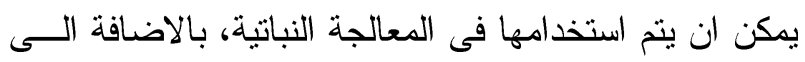

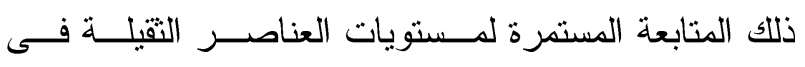
الاز اضى المروية بمياه الصرف المعالجة امر ضــرورى لضمان الاستخدام الامن لهذة الار اضى. لهئ. المنوفية- مصر • وتم تقدير محتوى العناصر الثقيلة المشار اليها فى العينات التى تم الحصول عليها. اوضحت النتــائج

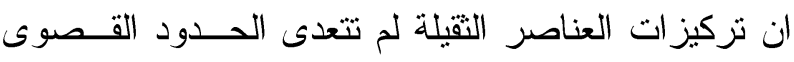
المسموح بها في التربة و النبات. تركيز العناصر التقيلة فى عبنات الاشجار النامية فى الارض المروية بمياه الــصرف المعالج كانت اعلى من النباتات النامية فى الارض المروية

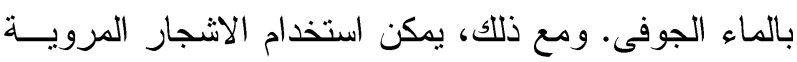
بمياه الصرف المعالج فى العديد من الاستخدامات حيث ان 